\title{
DENGUE EXPANDED SYNDROME: AN UNUSUAL PRESENTATION
}

\author{
QUAZI TARIKUL ISLAM ${ }^{1}$, HOMAYRA TAHSEEN HOSSAIN ${ }^{2}$, MD. ABULKASHEM KHANDAKER ${ }^{3}$, HAM \\ NAZMUL AHASAN ${ }^{4}$, MAKSUDUL MAJUMDER $^{5}$, TAJNUVA JABEEN ${ }^{6}$
}

\begin{abstract}
:
Dengue fever is a mosquito borne viral infection found in tropic \& sub-tropic regions. The symptomatic dengue infection follows an uncomplicated course; however, unusual manifestations of this disease are now being increasingly reported as expanded dengue syndrome which incorporates wide spectrum of uncommon presentation of this common disease which does not fall into either dengue shock syndrome or dengue hemorrhagic fever. We report a case of a 30 year old lady who presented with high grade fever, rash, diffuse abdominal pain \& vomiting, who ultimately developed shock and features of multi organ failure. We diagnosed her as a case of expanded dengue syndrome with multi organ failure ( hepatitis with very high transaminase levels, pancreatitis, acalculous cholecystitis, coagulation failure \& acute kidney injury) with septicaemia. With prompt diagnosis and aggressive management, this potentially fatal patient was cured.
\end{abstract}

Key Words:Dengue fever, expanded dengue syndrome, multi organ failure

Received: 10 November 2017

Accepted: 28 November 2017

DOI: http://dx.doi.org/10.3329/bjmed.v29i1.35408

\section{Introduction}

Dengue fever is a viral infection of rainy season, transmitted by the mosquito AedesAegypti. AedesAegypti mosquito is found in tropic \&subtropic regions $\&$ is commonly known to flourish due to unplanned urbanization \& poor control measures. The symptomatic dengue infection follows an uncomplicated course; however, unusual manifestations of this disease are now being increasingly reported as expanded dengue syndrome which incorporates wide spectrum of uncommon presentation of this common disease. Expanded dengue is a terminology developed in the WHO guidelines of year 2012. ${ }^{1}$ Unusual manifestations of patients with severe organ involvement such as liver, kidneys, brain or heart associated with dengue infection have been increasingly reported in dengue hemorrhagic fever (DHF) and also in dengue patients who do not have evidence of plasma leakage. These unusual manifestations maybe associated with coinfections, co-morbidities or complications of prolonged shock and can be clubbed under the expanded dengue syndrome. The unusual manifestations may be underreported or unrecognized or not related to dengue. These atypical manifestations may be potentially serious and may result in increased rates of morbidity and mortality, which can be preventable with prompt diagnosis and judiciary management. Therefore, clinicians should be aware of these atypical manifestations.

We report a case of expanded dengue syndrome in a 30 year old lady with hepatitis with very high level of liver enzymes, acute kidney injury and septicaemia. The purpose of our case reporting is to throw light on atypical manifestations of dengue, especially during ongoing epidemics.

\section{Case Report}

A 30-year-old lady presented with high grade fever for 5 days, together with vomiting and diffuses abdominal pain for 3 days. She had aches and pain of body from the onset of fever. She was conscious but drowsy, she had rash all over the body and was having heavy flow of menstrual cycle. She was non-diabetic, normotensive. On examination both of her eyes were congested, Pulse- 112/min, normal volume, BP- 100/ $60 \mathrm{mmHg}$, Temp $104.4^{\mathrm{O}} \mathrm{F}$, Respiratory rate $22 /$

1. Professor of Medicine, Popular Medical College Hospital, Dhaka

2. Associate Professor, Medicine, Popular Medical College Hospital, Dhaka

3. Professor \& Head of Medicine, Popular Medical College Hospital, Dhaka

4. Professor of Medicine, Popular Medical College Hospital, Dhaka

5. Registrar, Medicine, Popular Medical College Hospital, Dhaka

6. Assistant Registrar, Medicine, Popular Medical College Hospital, Dhaka

Address of correspondence: Professor QuaziTarikul Islam, Professor of Medicine, Popular Medical College Hospital, Dhaka. Email: prof.tarik@gmail.com

Bangladesh J Medicine 2018; $29: 45-47$ 
Table 1

Investigation Profile

\begin{tabular}{|c|c|c|c|c|c|}
\hline \multicolumn{6}{|c|}{ Table 1: Investigation Profile } \\
\hline \multirow{2}{*}{\multicolumn{2}{|c|}{$\begin{array}{l}\text { TC } \\
\mathrm{DC}: \mathrm{N}+\mathrm{L}+\mathrm{M}+\mathrm{E}+\mathrm{B}\end{array}$}} & $7640 \times 10^{9} / \mathrm{L}$ & \multirow{2}{*}{$\begin{array}{l}\text { Urine } \\
\mathrm{R} / \mathrm{M} / \mathrm{E}\end{array}$} & Pus Cell & $0-2 / \mathrm{HPF}$ \\
\hline & & $\begin{array}{l}38 \%+55 \%+5 \%+2 \%+ \\
0 \%\end{array}$ & & RBC & Plenty \\
\hline \multicolumn{2}{|l|}{ Haemoglobin } & $9.6 \mathrm{~g} / \mathrm{dL}$ & \multicolumn{2}{|l|}{$\begin{array}{l}\text { X- Ray } \\
\text { Chest }\end{array}$} & $\begin{array}{l}\text { Right sided pleural } \\
\text { effusion }\end{array}$ \\
\hline \multicolumn{2}{|l|}{ Platelet Count } & $12,000 / \mathrm{mm}^{3}$ & \multicolumn{2}{|c|}{ USGW/A } & $\begin{array}{l}\text { Moderate ascites, } \\
\text { cholecystitis }\end{array}$ \\
\hline \multicolumn{2}{|l|}{ ESR } & $40 \mathrm{~mm}$ & \multirow{8}{*}{$\begin{array}{l}\text { Viral } \\
\text { Markers }\end{array}$} & HBsAg & Negative \\
\hline \multicolumn{2}{|l|}{ Haematocrit } & $50 \%$ & & Anti HAV IgM & Negative \\
\hline \multicolumn{2}{|l|}{ LDH } & $16,611 \mathrm{U} / \mathrm{L}$ & & Anti HEV IgM & Negative \\
\hline \multirow{4}{*}{$\begin{array}{l}\text { Liver Function } \\
\text { Panel }\end{array}$} & SGOT & $8957 \mathrm{U} / \mathrm{L}$ & & Dengue NS1 Ag & Negative \\
\hline & SGPT & $3438 \mathrm{U} / \mathrm{L}$ & & \multirow[t]{4}{*}{ Dengue IgM } & \multirow[t]{4}{*}{ Positive } \\
\hline & S. Albumin & $3.07 \mathrm{gm} / \mathrm{dl}$ & & & \\
\hline & S. bilirubin & $1.2 \mathrm{mg} / \mathrm{dl}$ & & & \\
\hline \multirow{2}{*}{$\begin{array}{l}\text { Renal Function } \\
\text { Panel }\end{array}$} & Blood Urea & $11.6 \mathrm{mmol} / \mathrm{L}$ & & & \\
\hline & S. Creatinine & $1.9 \mathrm{mg} / \mathrm{dL}$ & \multirow[t]{5}{*}{$\mathrm{ABG}$} & $\mathrm{pH}$ & 7.3 \\
\hline \multirow{5}{*}{$\begin{array}{l}\text { Serum } \\
\text { Electrolytes }\end{array}$} & $\mathrm{Na}^{+}$ & $126 \mathrm{mmol} / \mathrm{L}$ & & $\mathrm{PCO} 2$ & 18 \\
\hline & $\mathrm{K}^{+}$ & $4.1 \mathrm{mmol} / \mathrm{L}$ & & $\mathrm{PO} 2$ & 112 \\
\hline & $\mathrm{HCO}^{3-}$ & $20 \mathrm{mmol} / \mathrm{L}$ & & $\mathrm{HCO} 3$ & 9.3 \\
\hline & $\mathrm{Ca}^{++}$ & $8.8 \mathrm{mg} / \mathrm{dL}$ & & $\mathrm{BE}$ & 11.4 \\
\hline & $\mathrm{Mg}^{++}$ & $2.6 \mathrm{mg} / \mathrm{dL}$ & & & \\
\hline \multirow{4}{*}{$\begin{array}{l}\text { Coagulation } \\
\text { Profile }\end{array}$} & PT/ INR & $35 \mathrm{~s}$ (control-12 sec) & & & \\
\hline & APTT & $58 \mathrm{~s}$ & & & \\
\hline & FDP & 65 & & & \\
\hline & D-Dimer & $>5$ & & & \\
\hline Pancreatic Profile & S. Lipase & $458 \mathrm{U} / \mathrm{L}$ & & & \\
\hline
\end{tabular}

min.There was diffuse abdominal tenderness without any organomegaly. Breath sound was diminished in the lower part of both lungs.

Initial management was done by IV Normal saline, IV antiemetic, IV Proton Pump Inhibitor, Paracetamol as per WHO Dengue Fever protocol.

On the day of admission, she developed respiratory distress.On the second day of presentation she developed profound shock with reduced urinary output. She was then transferred to the intensive care unit for better monitoring and management.

The investigations of her illness are depicted in Table 1

Very high level of liver enzymes (AST>ALT) with normal bilirubin \& negative viral markers indicate this anicteric hepatitis is due to dengue infection, which is a component of expanded dengue syndrome. Investigation profile revealed the patient had been suffering from septicaemia with multi organ failure (liver, kidney, haemopoietic system, pancreas, gall bladder) due to dengue infection, which is evident by positive Dengue IgM.
We diagnosed the patient as Expanded Dengue Syndrome and promptly started management symptomatically. Ultimately the patient required two units of aphertic platelet, four units of platelet concentrate, six units of FFP along with other managements.

From the $6^{\text {th }}$ day of presentation she showed signs of improvement both clinically and biochemically. She was later discharged with full recovery.

\section{Discussion}

Dengue is the most rapidly spreading mosquito borne viral disease in the world ${ }^{2}$ and as larger proportion of population is being affected, more unusual manifestations are being reported. Presentation of dengue viral infection is variable, ranging from asymptomatic viral infection to life threatening dengue shock syndrome. In 2011 revised WHO guidelines, dengue was divided into dengue fever (DF), dengue hemorrhagic fever (DHF) without shock or with shock (DSS) and expanded dengue syndrome ${ }^{3}$.Expanded 
dengue syndrome is a new entity added to the classification system to incorporate a wide spectrum of unusual manifestations of dengue infection affecting various organ systems including gastrointestinal, hepatic, neurological ${ }^{4}$, pulmonary, renal system\& other isolated organ involvements expressed as complications of severe profound shock or associated host conditions or co- infections.

The atypical manifestations noted in dengue can be mutisystemic and multifacetal. In clinical practice, the occurrence of atypical presentation should prompt us to investigate for dengue. Knowledge of expanded dengue helps to clinch the diagnosis of dengue early, especially during ongoing epidemics, avoiding further battery of investigations. ${ }^{5}$

Our patient's initial presentation was with high grade fever, rash and generalized body ache, which was typical of dengue fever. On the third day of her illness, she developed diffuse abdominal pain and vomiting.Investigations revealed markedly elevated level of liver enzymes with normal serum bilirubin level \& raised serum lipase level. Ultrasonography of whole abdomen revealed presence of ascites \& acalculuscholecystitis. So, there was acute anicteric hepatitis, pancreatitis $\&$ cholecystitis- all contributing to her abdominal pain.

The patient was admitted on the $5^{\text {th }}$ day of her illness, so Dengue NS1 antigen was negative. Dengue IgM antibody was positive, indicating primary infection. Altered liver function test is common in dengue, but such a high level of AST \& ALT is very unusual. AST elevation is usually greater than ALT in dengue ${ }^{6}$, as we found in our patient.Gastrointestinal manifestations of expanded dengue syndrome are variable including hepatic dysfunction, acalculuscholecystitis fulminant hepatic failure, acute pancreatitis, diffuse peritonitis and so on ${ }^{7}$. The levels of aminotransferases (usually not more than $100 \mathrm{U})$ generally reach maximum values around the ninth day after the first episode of fever and gradually taper off toward normality within two weeks. DSS is associated with higher mortality than $\mathrm{DHF}^{7}$.Acalculouscholecystitis has been documented in many case reports. Asymptomatic gall bladder edema as an ultrasound examination finding can be a surrogate marker of dengue before arrival of laboratory investigations report.Cholecystectomy is not advised, however, a close watch for impending gangrenous gall bladder is a must ${ }^{8}$.

Renal involvement in dengue is uncommon as compared to other organ involvement. The commonest renal presentation is that of a pre-renal acute kidney injury (AKI) related to third space fluid loss and dehydration ${ }^{9}$.Our patient also developed AKI with hyponatraemia with haematuria. There was evidence of plasma leakage, as evidenced by ascites, pleural effusion and raised haematocrit level. The patient had severe thrombocytopenia \& raised prothrombin time \& APTT. Bleeding manifestations were in the form of haematuria \& menorrhagia.

Due to multisystem involvement with septicaemia in this seropositive dengue patient, we labeled her as Expanded Dengue Syndrome and managed aggressively in ICU with all possible supportive measures. Though her overall condition was very critical, from the $6^{\text {th }}$ day of presentation, she showed signs of improvement both clinically and biochemically. This is the beauty of clinical medicine \& rewards for the clinicians- bringing back to life.

\section{Reference}

1. World Health organization Comprehensive guidelines for prevention and treatment of dengue and dengue hemorrhagic fever. New Delhi: WHO, SEARO; revised and expanded edition.

2. WHO: Dengue. Guidelines for diagnosis, treatment, prevention and control. New edition. World Health Organization, Geneva; 2009.

3. WHO. Comprehensive guidelines for prevention and control of dengue and dengue hemorrhagic fever. World Health Organization, Regional Office for South-East Asia; 2011. Revised and expanded

4. Solomon T, Dung NM, Vaughn DW. et al. Neurological manifestations of dengue infection. Lancet. 2000;355(9209): 1053-1059. doi: 10.1016/S0140-6736(00)02036-5.

5. DB Kadam, SonaliSalvi, Ajay Chandanwale. Expanded Dengue- Review article. Journal of The Associations of Physicians of India. Vol 64. July 2016

6. Lee LK, Gan VC, Lee VJ, et al. Clinical relevance and discriminatory value of elevated liver aminotransferase levels for dengue severity. PLoSNeg1 Trop Dis 2012; 6:e1676.

7. Macedo C. Histologic, Viral, and Molecular Correlates of Dengue Fever Infection of the Liver Using Highly Sensitive Immunohistochemistry. Diagn Molecular Pathol 2006; 15:223-228.

8. Sharma N, Mahi S, BhallaA et al. Dengue fever related acalculouscholecystitis in a North Indian tertiary care hospital. J GastroenterolHepatol 2006; 21:664-667.

9. Kuo et al. Impact of Renal Failure on the Outcome of Dengue Viral Infection. Clin J Am SocNephrol 2008; 3:1350-1356. 